УДК 330.34

\title{
СУЧАСНА ПОЛІТИКА НБУ ЩОДО РОЗВИТКУ СТАЛОГО ФІНАНСУВАННЯ
}

\section{CURRENT NBU POLICY ON THE DEVELOPMENT OF SUSTAINABLE FINANCING}

\author{
Прутська Олена Олексіївна \\ доктор економічних наук, профресор, \\ Вінницький торговельно-економічний інститут \\ Київського національного торговельно-економічного університету \\ ORCID: https://orcid.org/0000-0002-6273-3330
}

Prutska Olena

Vinnytsia Institute of Trade and Economics

of Kyiv National University of Trade and Economics

\begin{abstract}
Стаття присвячена актуальним питанням фрінансування сталого розвитку та завдань НБУ щодо його забезпечення. Розкрито зміст категорій «стале фрінансування», «сталий розвиток», «фінансування сталого розвитку», «зелене фрінансування». Обґрунтовано висновок, що фрормування сталого фрінансування залежить від політики головного регулятора фрінансового ринку - центрального банку. Досліджено стратегічні підходи НБУ до побудови та розвитку сталого фрінансування в Україні, визначено фрункції НБУ щодо забезпечення сталого фрінансового сектору, заходів для есрективного використання фінансових ресурсів у забезпеченні сталого розвитку. Узагальнено цілі, завдання і напрями діяльності НБУ щодо розвитку сталого фрінансування. Проаналізовано зміст та основні напрями Політики НБУ щодо розвитку сталого фрінансування на період до 2025 року. Досліджено перший досвід сталого фрінансування в Україні та окреслено основні напрями його розвитку.

Ключові слова: центральний банк, НБУ, сталий розвиток, стале фінансування, фрінанси сталого розвитку, зелене фрінансування.
\end{abstract}

Статья посвящена актуальным вопросам финансирования устойчивого развития и заданий НБУ по его обеспечению. Раскрыто содержание категорий «устойчивое фринансирование» «устойчивое развитие», «финансирование устойчивого развития», «зеленое фринансирование». Обоснован вывод о том, что фрормирование устойчивого фринансирования зависит от политики главного регулятора фринансового рынка - центрального банка. Исследованы стратегические подходы НБУ к построению и развитию устойчивого фринансирования в Украине, определены функции НБУ по обеспечению устойчивости финансового сектора, проведению мероприятий, направленных на эфрфективное использование фринансовых ресурсов для устойчивого развития. Проанализированы содержание и основные положения документа «Политика НБУ по развитию устойчивого фринансирования на период до 2025 года». Исследован первый опыт устойчивого фринансирования в Украине и очерчены основные направления его развития.

Ключевые слова: центральный банк, НБУ, устойчивое развитие, устойчивое фринансирование, фринансы устойчивого развития, зеленое фринансирование.

The article is devoted to topical issues of financing sustainable development and the tasks of the NBU to ensure it. The urgency of the topic is determined by the fact that global problems in the field of sustainable development in recent years have increased under the influence of trends such as climate change, economic and social dynamics, consequences of the COVID-19 pandemic, technological advances and environmental degradation. According to a report by the International Finance Corporation (IFC), globally in emerging markets, there are opportunities for climate investment worth about 23 trillion. USD by 2030, while in Ukraine they are estimated at 73 billion USD. To take advantage of this potential, countries need to adopt appropriate standards and develop policies to build a sustainable financial sector. This task is directly related to the activities of the NBU. The conclusion is substantiated that the formation of sustainable financing depends on the policy of the main regulator of the financial market - the central bank. The purpose of the article is to study the strategic approach of the NBU to the construction and future development of sustainable financing in Ukraine, to determine the functions of the NBU to ensure a sustainable financial sector, measures for effective use of financial resources in sustainable development. The content of the categories "sustainable financing", "sustainable development", "sustainable development financing", "green financing" is revealed. The strategic approaches of the 
NBU to the construction and development of sustainable financing in Ukraine are studied, the functions of the NBU on ensuring a sustainable financial sector, measures for the efficient use of financial resources in ensuring sustainable development are determined. The goals, tasks and directions of the NBU's activity on the development of sustainable financing are summarized. The content and main directions of the NBU Policy on the development of sustainable financing for the period up to 2025 are analyzed. The first experience of sustainable financing in Ukraine is studied. The conducted analysis and the received results will allow to carry out specification of the basic directions of improvement of activity of NBU concerning development of sustainable financing.

Keywords: central bank, NBU, sustainable development, sustainable financing, sustainable development finance, green financing.

Постановка проблеми. Цілі і завдання сталого розвитку, визначені у підсумковому документі саміту $\mathrm{OOH}$ «Перетворення нашого світу: порядок денний у сорері сталого розвитку до 2030 р.», вимагають активізації дій всіх гравців та інституцій сучасного світу. Забезпечення сталого розвитку за останні роки ускладнилося під впливом таких фракторів, як зміна клімату, зміна економічної і соціальної динаміки, наслідки пандемії COVID-19, технологічні досягнення і викликане ними погіршення природного середовища. У всьому світі визнають вплив кліматичних фракторів на фрінансову стабільність. Принципи сталого розвитку поступово поширюються на всі сорери економічної діяльності, зокрема й на сореру фрінансів. З'явилося нове поняття «стале фрінансування». Стале фрінансування визначає новий підхід до прийняття інвестиційних рішень. Важливо, що стале фрінансування вважається вкрай важливим для процесу перетворень, спрямованих на перехід до низьковуглецевої економіки і міцної фрінансової системи. Глобальні зусилля спрямовані на створення умов, що відповідають наступним основним цілям:

- переорієнтація потоків капіталу на стійкі інвестиції з метою досягнення стійкого і всеосяжного зростання;

- управління фрінансовими ризиками, пов'язаними зі зміною клімату, погіршенням стану довкілля та соціальними питаннями;

- сприяння прозорості та довгостроковості в глобальній фрінансовій та економічній діяльності.

За даними звіту Міжнародної орінансової корпорації (IFC), у глобальному масштабі на ринках, що розвиваються, до яких відноситься й Україна, існують можливості для кліматичних інвестицій на суму близько 23 трлн. доларів США до 2030 р., при цьому в Україні вони оцінюються в 73 млрд. доларів США [7]. Щоб скористатися цим потенціалом, країні необхідно прийняти відповідні стандарти та розробити політику для побудови сталого фрінансового сектору. Це завдання безпосередньо стосується діяльності НБУ і, як показує прак- тика, втілюється в конкретні документи. Отже, аналіз основних положень політики НБУ щодо розвитку сталого фрінансування $€$ важливим науковим і практичним завданням.

Аналіз останніх досліджень та публікацій. Концепція сталого розвитку та її принципи, проблеми імплементації цих принципів в практику господарювання останнім часом перебуває в центрі уваги вчених-економістів. Значний внесок у вивчення окремих теоретичних аспектів процесів сталого розвитку і розробку практичних рекомендацій зробили такі вітчизняні та зарубіжні дослідники, як $€$. Буравльов [1], І. Васильчук [2], О. Веклич [3], В. Власюк [4], А. Єфремов, Г. Кларк, Л. Корнійчук, Т. Кожухова [5], О. Осауленко, В. Савчук, В. Семиноженко, Й. Шумпетер, А. Чешин та інші.

Водночас концепції фрінансів сталого розвитку і сталого фрінансування поки що не знайшли достатнього висвітлення у вітчизняній економічній літературі. Слід відзначити дослідження І. Васильчук, яка обґрунтувала, що концепція фрінансів сталого розвитку поступово набуває як теоретичного обґрунтування, так і практичного підтвердження, що дозволяє ввести термін «фрінанси сталого розвитку» у академічний дискурс [2, с. 213].

Суттєвим $€$ внесок Т. Кожухової в дослідження джерел фрінансування сталого розвитку; визначенні заходів для ефрективного використання міжнародних та національних фрінансових ресурсів у його забезпеченні [5, с. 218].

Огляд літературних джерел показав, що поняття сталого фрінансування як нового явища, що знаходиться на стадії свого становлення, ще не має належного теоретикометодологічного обґрунтування і потребує детального дослідження його теоретичних та практичних аспектів, зокрема в частині ролі НБУ щодо його розвитку.

Метою статті $\epsilon$ дослідження стратегічного підходу НБУ до побудови та майбутнього розвитку сталого фрінансування в Україні, визначення фрункцій НБУ щодо забезпечення сталого фрінансового сектору, заходів для 
есрективного використання фрінансових ресурсів у забезпеченні сталого розвитку.

Виклад основного матеріалу дослідження. Перш за все, необхідно визначити що розуміє сучасна економічна наука під «сталим фрінансуванням». В останніх дослідженнях і публікаціях висвітлюються поняття «сталого розвитку», «фрінансування сталого розвитку», «зеленого фрінансування», «зеленого банкінгу». Так, на думку І.П. Васильчук, фрінанси сталого розвитку уявляють собою систему фрінансування, яка надає фрінансовий капітал у специсрічній формі - бридж-фрінансування (від англійського слова «Bridge» - міст, місток), що поєднує в собі різні характеристики. Фінанси сталого розвитку, на думку І.П. Васильчук, дозволяють поєднувати фрінансові і несрінансові цілі як провайдерів капіталу, так і його споживачів, та займають проміжне положення між традиційними фрінансами, з їх орієнтацією на досягнення фрінансової вигоди, та фрілантропією [2, с. 215]. Важливим висновком автора $€$ розуміння фрінансування сталого розвитку як свого роду імпакт-інвестицій, спрямованих на досягнення позитивного соціального ефректу. В узагальненому вигляді типологізація системи фрінансів сталого розвитку представлена в таблиці 1.

T. Кожухова обґрунтувала конфрігурацію глобальної системи фрінансування сталого розвитку, що являє собою сукупність взаємопов'язаних елементів національного, міжнародного і світового рівнів [6, с. 3-4].
В розробленому Національним банком України документі - Політика НБУ щодо розвитку сталого фрінансування на період до 2025 року (далі - Політика щодо розвитку сталого фрінансування) - наведено визначення сталого фрінансування. Стале фрінансування розуміється як інтеграція екологічних, соціальних та управлінських критеріїв (ESG) у фрінансові послуги для досягнення результатів сталого розвитку, включаючи пом'якшення та адаптацію до несприятливих наслідків зміни клімату [9].

Слід зазначити, що поняття «сталого фрінансування» по суті багато в чому збігається 3 поняттям «зеленого банкінгу», що $є$, за визначенням О. Веклич, «екологічно дружньою фрілософрією ведення бізнесу в банківському секторі, яка просуває використання ресурсозберігаючих екологічно безпечних технологій та продуктів для зменшення шкоди довкіллю внаслідок операційної діяльності фрінансових інституцій щодо стимулювання запровадження екологічних проектів на засадах екологічно й соціально відповідального фрінансування» [3, с. 240]. Інструменти механізму реалізації «зеленого банкінгу», серед яких «зелені» інвестиції, «зелене» страхування, пільгові кредитні ставки, позики, «зелена» іпотека, часткові кредитні гарантії для здійснення «зелених» проектів тощо, фрактично $€$ інструментами реалізації цілей сталого фрінансування. Це дозволяє розглядати «зелений банкінг» як складову сталого фрінансування.

Таблиця 1

Типологізація системи фрінансів сталого розвитку за І.П. Васильчук

\begin{tabular}{|c|c|c|c|c|}
\hline & \multirow[b]{2}{*}{$\begin{array}{c}\text { Традиційні } \\
\text { фрінанси }\end{array}$} & \multicolumn{2}{|c|}{ Фінанси сталого розвитку } & \multirow[b]{2}{*}{$\begin{array}{l}\text { Філантропічні } \\
\text { фрінанси }\end{array}$} \\
\hline & & $\begin{array}{c}\text { Соціально } \\
\text { відповідальні } \\
\text { рінанси } \\
\text { (інвестування } \\
\text { з урахуванням } \\
\text { чинників сталого } \\
\text { розвитку) }\end{array}$ & \begin{tabular}{|c|} 
Соціально \\
орієнтовані \\
фрінанси \\
(інвестування \\
у позитивний \\
соціальний \\
ефект)
\end{tabular} & \\
\hline $\begin{array}{c}\text { Цільова } \\
\text { орієнтація }\end{array}$ & $\begin{array}{c}\text { Тільки фрінансові } \\
\text { цілі } \\
\end{array}$ & $\begin{array}{c}\text { Фінансові та } \\
\text { не фрінансові цілі }\end{array}$ & $\begin{array}{l}\text { Неорінансові та } \\
\text { фрінансові цілі }\end{array}$ & $\begin{array}{c}\text { Тільки } \\
\text { не фрінансові цілі }\end{array}$ \\
\hline $\begin{array}{l}\text { Очікуваний } \\
\text { результат }\end{array}$ & $\begin{array}{c}\text { Тільки фрінансова } \\
\text { вигода }\end{array}$ & $\begin{array}{c}\text { Пріоритет - } \\
\text { фрінансова } \\
\text { вигода, на } \\
\text { другому місці - } \\
\text { соціальний } \\
\text { ефрект } \\
\end{array}$ & $\begin{array}{c}\text { Пріоритет - } \\
\text { позитивний } \\
\text { соціальний } \\
\text { ефект, на } \\
\text { другому місці - } \\
\text { фрінансова вигода } \\
\end{array}$ & $\begin{array}{c}\text { Тільки } \\
\text { позитивний } \\
\text { соціальний } \\
\text { ефрект }\end{array}$ \\
\hline $\begin{array}{c}\text { Фінансові } \\
\text { інструменти }\end{array}$ & $\begin{array}{l}\text { Традиційні } \\
\text { активи }\end{array}$ & \multicolumn{2}{|c|}{$\begin{array}{c}\text { Інноваційні фрінансові інструменти } \\
\text { на основі зближення комерційного } \\
\text { та некомерційного підходів }\end{array}$} & Гранти, пожертви \\
\hline
\end{tabular}


Таким чином, можна узагальнити, що стале фрінансування має на меті фрінансування для досягнення результатів сталого розвитку. В системі інститутів, які повинні сприяти розвитку сталого фрінансування, важливе місце належить центральному банку країни. Слід зазначити, що НБУ активно підключився до цієї діяльності. 3 квітня 2021 р. активно розпочалася співпраця НБУ з Міжнародною фрінансовою корпорацією (IFC) з метою підтримки країни в досягненні її цілей щодо переходу до низьковуглецевої, гнучкої і витривалої економіки. Метою Проекту $€$ розвиток сталого фрінансування в Україні шляхом розроблення стандартів «зеленого фрінансування» й інтегрованих екологічних, соціальних та управлінських стандартів. У наступні 3 роки в межах співпраці НБУ та IFC передбачається:

- розроблення стратегій НБУ щодо «зеленого» та сталого фрінансування;

- розроблення стандартів сталого та «зеленого» фрінансування в Україні;

- розбудова спроможності НБУ щодо включення аспектів ESG до нормативно-правових актів про корпоративне управління в банках України та стандартів розкриття інорормації про ESG для банків, розроблення вимог з управління екологічними й соціальними ризиками в банках;

- обмін знаннями і розбудова спроможНОсті НБУ;
- здійснення заходів із підвищення обізнаності для установ, що є об'єктами регулювання з боку НБУ [8].

Детальний опис задач НБУ та нового інструментарію для наближення діяльності українських орінансових установ до кращих світових стандартів інтеграції екологічних, соціальних та управлінських критеріїв (ESG) у фінансові послуги узагальнено у таблиці 2.

НБУ розроблена Дорожня карта з розвитку сталого фрінансування. Мета Дорожньої карти - визначити дії Національного банку України зі створення надійних, передбачуваних та стабільних регуляторних засад для розвитку в країні сталого фрінансування із зазначенням конкретних часових меж та 3 урахуванням необхідності забезпечення послідовності та адаптації банківської системи та небанківських фрінансових установах (далі - НФУ) до змін (табл. 3).

Ознайомлення з наведеним планом дій дає підстави зробити висновок, що він фокусуватиметься на зеленому фрінансуванні та належних екологічних, соціальних та управлінських стандартах (ESG), щоб допомогти українським банкам працювати у більш сталий спосіб.

Можна констатувати, що ідеї концепту сталого фрінансування поступово втілюються у вітчизняному банківському секторі. При цьому використовуються такі нові інструменти меха-

Місія, цілі і завдання політики НБУ щодо розвитку сталого фрінансування

Таблиця 2

\begin{tabular}{|c|c|c|}
\hline \multicolumn{3}{|c|}{ Основні характеристики політики НБУ щодо розвитку сталого фрінансування } \\
\hline Місія & 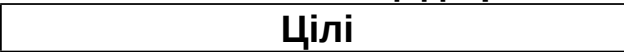 & Завдання \\
\hline $\begin{array}{l}\text { сорормувати цілісне } \\
\text { бачення ключових } \\
\text { засад розвитку сталого } \\
\text { срінансування в } \\
\text { Україні та необхідних } \\
\text { для їх реалізації дій } \\
\text { Національного банку } \\
\text { України з урахуванням } \\
\text { забезпечення } \\
\text { послідовності та } \\
\text { адаптації до змін як } \\
\text { банківської системи, так і } \\
\text { діяльності небанківських } \\
\text { фрінансових установ, що } \\
\text { сприятимуть фрінансовій } \\
\text { стабільності }\end{array}$ & $\begin{array}{l}\text { 1) сприяння сталому } \\
\text { економічному розвитку України; } \\
\text { 2) популяризація екологічної } \\
\text { свідомості й соціальної } \\
\text { відповідальності у фрінансовому } \\
\text { секторі України; } \\
\text { 3) сприяння дотриманню в } \\
\text { діяльності фрінансових установ, } \\
\text { що регулюються Національним } \\
\text { банком України, екологічних } \\
\text { цілей, принципів сталої } \\
\text { економічної діяльності та } \\
\text { принципу енергоесективності як } \\
\text { першочергового, визначених згідно } \\
\text { із Європейським Зеленим Пактом; } \\
\text { 4) сприяння розвитку в Україні } \\
\text { економіки замкненого циклу } \\
\text { як вирішального фрактору } \\
\text { у досягненні кліматично } \\
\text { нейтральної, ресурсоефрективної } \\
\text { та конкурентоспроможної } \\
\text { економіки в Україні }\end{array}$ & $\begin{array}{l}\text { 1) вдосконалити } \\
\text { корпоративне управління } \\
\text { банків та небанківських } \\
\text { фрінансових установ } 3 \\
\text { урахуванням ESG факторів; } \\
\text { 2) запровадити вимоги з } \\
\text { управління екологічними } \\
\text { та соціальними ризиками у } \\
\text { фрінансових установах, діяль- } \\
\text { ність яких регулюється НБУ; } \\
\text { 3) запровадити стандарти } \\
\text { з розкриття фрінансовими } \\
\text { установами інфрормації про } \\
\text { ESG; } \\
\text { 4) проведення заходів з } \\
\text { підвищення рівня фрінансової } \\
\text { грамотності населення у } \\
\text { питаннях розвитку в Україні } \\
\text { сталого фрінансування; } \\
\text { 5) урахування кліматичних } \\
\text { змін при забезпеченні } \\
\text { фрінансової стабільності }\end{array}$ \\
\hline
\end{tabular}

Джерело: укладено автором на основі [8] 
Основні напрями діяльності НБУ з розвитку сталого фінансування

\begin{tabular}{|l|l|}
\hline & \multicolumn{1}{|c|}{ Напрями діяльності НБУ } \\
\hline 1 & Удосконалення корпоративного управління в банках та НФУ щодо фракторів ESG \\
\hline 2 & Розроблення стандартів із розкриття банками та НФУ інфрормації про ЕSG \\
\hline 3 & Розроблення вимог з управління банками та НФУ екологічними та соціальними ризиками \\
\hline 4 & $\begin{array}{l}\text { Установлення фрінансовим установам критеріїв оцінки та відбору проєктів для } \\
\text { фінансування з урахуванням їх ролі в сталому розвитку }\end{array}$ \\
\hline 5 & $\begin{array}{l}\text { Забезпечення розкриття фрінансовими установами інфрормації про те, наскільки сталою } є \\
\text { їх діяльність }\end{array}$ \\
\hline 6 & Інтеграція кліматичних аспектів у систему забезпечення фрінансової стабільності \\
\hline 7 & $\begin{array}{l}\text { Організація роботи та здійснення заходів із підвищення рівня фрінансової обізнаності } \\
\text { суб'єктів економічної діяльності в питаннях розвитку в Україні сталого фрінансування }\end{array}$ \\
\hline
\end{tabular}

Джерело: укладено автором на основі [8]

нізму надання грошових кредитних ресурсів, як пільгові кредитні ставки, пролонгований термін позики для широкомасштабних природоохоронних проектів (або для будівництва приватного «зеленого» житла), надання позик, кредитів або інших послуг для придбання сертифрікатів на викиди забруднюючих речовин, продаж фрінансовими установами муніципальних облігацій, призначених для фрінансування проектів захисту довкілля тощо.

Прикладом сталого фрінансування можна вважати кредит у розмірі 30 млн. євро задля зеленого фрінансування., який Чорноморський банк торгівлі та розвитку (ЧБТР) надає Укргазбанку. Зокрема, кошти виділені на фрінансування енергоефективності, відновлюваної енергетики та інших проєктів, спрямованих на покращення екології, з метою зменшення негативного вуглецевого впливу української промисловості. На сьогодні Укргазбанк $€$ беззаперечним лідером у «зеленому» срінансуванні. Станом на кінець 2019 року частка зелених позик у кредитному порторелі Укргазбанку становила близько $30 \%$.

АТ АКБ «Львів» надав позику на €3 млн. понад 1400 домогосподарствам і шести компаніям, які інвестували в покращення енергоесрективності [3].

«Зелені облігації», які з'явились 2021 року в Україні, - також ефективний фрінансовий інструмент, який точно стане в нагоді бізнесу і державі для реалізації проектів «зеленого» спрямування [7]. Зелені облігації - це облігації, проспект яких передбачає використання залучених коштів виключно на фрінансування екологічного проекту або окремого його етапу. «Зелені» облігації вже використовуються для залучення орінансування в таких секторах, як виробництво та розподіл енергії, енергоефективне житло та низьковуглецева транспортна інфрраструктура.
Цілком зрозуміло, що НБУ повинен створити умови, за яких кредитно-фрінансовим установам запровадження «зелених» продуктів та послуг було б вигідно. Такими інструментами державної підтримки могли б бути, наприклад, пільгові кредитні програми, зниження облікової ставки НБУ для банків, які мають у своєму порторелі кредити на реалізацію екологоорієнтованих проектів, кредитні лінії для пріоритетного та субординованого боргу. Розробка політики НБУ щодо розвитку сталого фрінансування можна вважати певним етапом у фрормуванні відповідного законодавчого поля.

Висновки 3 даного дослідження і перспективи подальших розвідок у даному напрямі. Забезпечення умов для сталого розвитку є спільним завданням для всіх державних та наднаціональних інститутів. Стале фрінансування $€$ інструментом та необхідною складовою сталого розвитку. Формування сталого фрінансування залежить від політики головного регулятора фрінансового ринку центрального банку. Розроблена НБУ політика щодо розвитку сталого фрінансування розкриває компоненти сталого розвитку та сталих фрінансів, їх взаємозв'язок, визначає необхідні дії фрінансового регулятора для управління можливими ризиками, обумовленими як кліматичними викликами, так і екологічними проблемами; охоплює пов'язані з цим соціальні та управлінські питання. Нацбанк України розпочинає свій шлях до створення стійкої фрінансової системи, розширення зелених інвестицій в економіку, підтримки фрінансових продуктів, які мають позитивний вплив на клімат. Від повноти імплементації розроблених заходів значною мірою залежить успіх України у забезпеченні сталого розвитку. Оцінка ефективності запропонованих заходів $€$ предметом подальших досліджень у даному напрямі. 


\section{СПИСОК ВИКОРИСТАНИХ ДЖЕРЕЛ:}

1. Буравльов Є.П. Сталий (низькоентропійний) розвиток: український вимір. Вісник НАН України. 2010. № 9. С. 12-23.

2. Васильчук І.П. Фінанси сталого розвитку як відповідь на виклики постіндустріальної економіки. Проблеми економіки. 2015. № 2. С. 213-218.

3. Веклич О. «Зелений» банкінг: сутність, механізм та інструменти реалізації. URL: https://razumkov.org.ua/ uploads/article/2019_ZELEN_INVEST.pdf

4. Власюк В.Є. Фінансові аспекти упровадження концепції сталого розвитку економіки. Зовнішня торгівля: економіка, фрінанси та право. 2011. № 6. С. 107-111.

5. Кожухова Т.В. Стратегії фінансування сталого розвитку. Глобальні та національні проблеми економіки. 2014. Вип. 2. С. 218-221. URL: http://global-national.in.ua/archive/2-2014/45.pdf

6. Кожухова Т.В. Формування глобальної системи фінансування сталого розвитку : автореср. дис. ... д-ра екон. наук : 08.00.02 ; Донецьк. нац. ун-т. Вінниця. 2017. URL: https://abstracts.donnu.edu.ua/article/view/4068

7. Магомедов Р. Ми підтримуємо стале фрінансування і запроваджуємо зелені інструменти. URL: https://www.nssmc.gov.ua/my-pidtrymuiemo-stale-finansuvannia-i-zaprovadzhuiemo-zeleni-instrumenty-ruslanmahomedov-holova-nktspfr/

8. Нацбанк i IFC спільно розвиватимуть «зелене фрінансування». Економічна правда. URL: https://www.epravda.com.ua/news/2021/04/16/673095/

9. Політика щодо розвитку сталого фрінансування на період до 2025 року. URL: https://bank.gov.ua/ua/files/ IfTnWjOvMmYMCHE

\section{REFERENCES:}

1. Buravlov Ye.P. (2010) Stalyy (nyzkoentropiynyy) rozvytok: ukrayinskyy vymir [Sustainable (low entropy) development: the Ukrainian dimension]. Visnyk NAN Ukrayiny, 9, 12-23.

2. Vasylchuk I.P. (2015) Finansy staloho rozvytku yak vidpovid na vyklyky postindustrialnoyi ekonomiky [Sustainable finance in response to the challenges of the post-industrial economy]. Problemy ekonomiky, 2, 213-218.

3. Veklych O. «Zelenyy» bankinh: sutnist, mekhanizm ta instrumenty realizatsiyi [«Green» banking: the essence, mechanism and tools of implementation]. Retrieved from: https://razumkov.org.ua/uploads/article/2019_ZELEN_ INVEST.pdf (in Ukrainian)

4. Vlasyuk V.Ye. (2011) Finansovi aspekty uprovadzhennya kontseptsiyi staloho rozvytku ekonomiky [Financial aspects of implementing the concept of sustainable economic development]. Zovnishnya torhivlya: ekonomika, finansy ta pravo, 6, 107-111. (in Ukrainian)

5. Kozhukhova T.V. (2014) Stratehiyi finansuvannya staloho rozvytku [Strategies for financing sustainable development]. Hlobalni ta natsionalni problemy ekonomiky, 2, 218-221. Retrieved from: http://global-national.in.ua/ archive/2-2014/45.pdf

6. Kozhukhova T.V. (2017) Formuvannya hlobalnoyi systemy finansuvannya staloho rozvytku [Formation of a global system of financing sustainable development], extended abstract of Doctor's thesis. Vinnytsia. Retrieved from: https://abstracts.donnu.edu.ua/article/view/4068 (in Ukrainian)

7. Mahomedov R. My pidtrymuyemo stale finansuvannya i zaprovadzhuyemo zeleni instrument [We support sustainable financing and introduce green instruments]. Retrieved from: https://www.nssmc.gov.ua/my-pidtrymuiemo-stale-finansuvannia-i-zaprovadzhuiemo-zeleni-instrumenty-ruslan-mahomedov-holova-nktspfr/ (in Ukrainian)

8. Natsbank i IFC spilno rozvyvatymut «zelene finansuvannya» [The National Bank and IFC will jointly develop «green finance»]. Ekonomichna pravda. Retrieved from: https://www.epravda.com.ua/news/2021/04/16/673095/ (in Ukrainian)

9. Polityka shchodo rozvytku staloho finansuvannya na period do 2025 roku [Policy on the development of sustainable financing for the period up to 2025]. Retrieved from: https://bank.gov.ua/ua/files/lfTnWjOvMmYMCHE (in Ukrainian) 